\title{
A critical review on various feedstocks as sustainable substrates for biosurfactants production: a way towards cleaner production
}

\author{
Swayansu Sabyasachi Mohanty ${ }^{1,2}$, Yamini Koul ${ }^{1,2}$, Sunita Varjani ${ }^{{ }^{*}}$ (1), Ashok Pandey ${ }^{3}$, Huu Hao Ngo ${ }^{4}$, \\ Jo-Shu Chang ${ }^{5}$, Jonathan W. C. Wong ${ }^{6}$ and Xuan-Thanh Bui ${ }^{7,8}$
}

\begin{abstract}
The quest for a chemical surfactant substitute has been fuelled by increased environmental awareness. The benefits that biosurfactants present like biodegradability, and biocompatibility over their chemical and synthetic counterparts has contributed immensely to their popularity and use in various industries such as petrochemicals, mining, metallurgy, agrochemicals, fertilizers, beverages, cosmetics, etc. With the growing demand for biosurfactants, researchers are looking for low-cost waste materials to use them as substrates, which will lower the manufacturing costs while providing waste management services as an add-on benefit. The use of low-cost substrates will significantly reduce the cost of producing biosurfactants. This paper discusses the use of various feedstocks in the production of biosurfactants, which not only reduces the cost of waste treatment but also provides an opportunity to profit from the sale of the biosurfactant. Furthermore, it includes state-of-the-art information about employing municipal solid waste as a sustainable feedstock for biosurfactant production, which has not been simultaneously covered in many published literatures on biosurfactant production from different feedstocks. It also addresses the myriad of other issues associated with the processing of biosurfactants, as well as the methods used to address these issues and perspectives, which will move society towards cleaner production.
\end{abstract}

Keywords: Biosurfactant, Cleaner production, Agro-industrial waste, Municipal solid waste

\section{Introduction}

Surfactants are a diverse group of synthetic and biological compounds that all have a common tension-active property and are used in nearly all our everyday routine tasks [1]. The bulk of these surfactants are made from petroleum and are chemically synthesized [2]. In contrast, due to environmental concerns about chemical surfactants, the recent push for environmentally friendly technology has increased the use of microbial surfactants [3, 4].

Biosurfactants are gaining popularity due to their remarkable advantages over synthetic ones-low toxicity,

\footnotetext{
*Correspondence: drsvs18@gmail.com

${ }^{1}$ Gujarat Pollution Control Board, Gandhinagar, Gujarat 382 010, India

Full list of author information is available at the end of the article
}

biodegradability, efficacy over a broad $\mathrm{pH}$ and temperature range are just a few to name [5-7]. As a result, it is now used in a wide range of fields, including environmental [8-10], food [11, 12], remediation [13], biomedical [14-16], and a variety of other commercial applications [17-20]. The different feedstocks used, benefits, applications, and drawbacks of biosurfactants are depicted in Fig. 1.

These biosurfactants are produced under a wide range of growth and environmental conditions, and they are known to be primarily involved in enhancing the solubility and availability of different water-immiscible substrates. The members of the genera Pseudomonas, Bacillus, Rhodococcus, and Candida are predominantly used for the production of various biosurfactants [21].

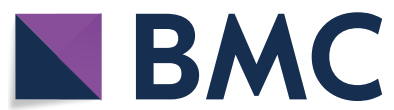

(c) The Author(s) 2021. This article is licensed under a Creative Commons Attribution 4.0 International License, which permits use, sharing, adaptation, distribution and reproduction in any medium or format, as long as you give appropriate credit to the original author(s) and the source, provide a link to the Creative Commons licence, and indicate if changes were made. The images or other third party material in this article are included in the article's Creative Commons licence, unless indicated otherwise in a credit line to the material. If material is not included in the article's Creative Commons licence and your intended use is not permitted by statutory regulation or exceeds the permitted use, you will need to obtain permission directly from the copyright holder. To view a copy of this licence, visit http://creativeco mmons.org/licenses/by/4.0/. The Creative Commons Public Domain Dedication waiver (http://creativecommons.org/publicdomain/ zero/1.0/) applies to the data made available in this article, unless otherwise stated in a credit line to the data. 


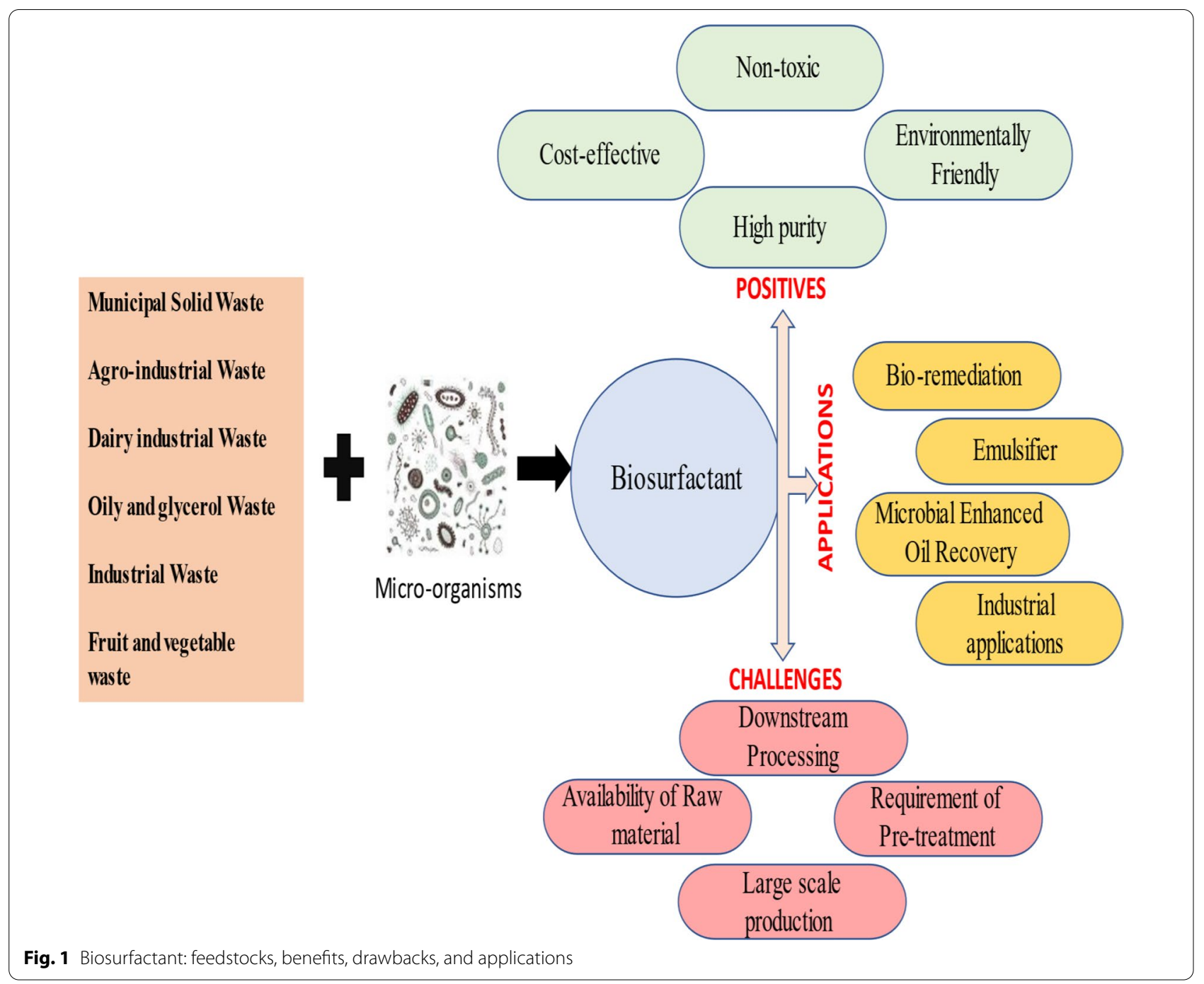

A typical biosurfactant is made up of two components: a hydrophilic component and a hydrophobic component [22-24]. The molecular weight, physicochemical properties, and mode of action of these compounds are being used to classify them. According to these combinations, there are low or high molecular weight biosurfactants [25]. The low-molecular-weight biosurfactants lower the surface and interfacial tensions whereas high-molecularweight biosurfactants, also recognized as bio emulsifiers, are better at stabilizing oil-in-water emulsions [26-28]. Among all currently recognised biosurfactants, Rhamnolipids, which is one of the glycolipids, has the greatest potential to become the next generation of biosurfactants [29]. Pseudomonas species is mainly used to produce these important groups of microbial surfactants around the world [10, 13]. To meet the high demand for biosurfactants, the production process has been scaled up and is now being used successfully at various biosurfactant production units. Figure 2 shows a schematic representation of the upscaling of the biosurfactant production.

According to a recent study, the global Biosurfactants market is anticipated to grow at a CAGR of 0.8 percent from US\$ 1.3754 billion in 2020 to US\$ 1.4427 billion in 2026 [30]. However, despite the high market demand, the cost of producing a biosurfactant is higher than that of synthetic ones [31]. Too much foaming while batch processing, lower yield, availability of affordable raw materials, expenses involved with downstream processing and purification, are still some challenges in biosurfactant production at the industrial scale [32-34]. As a result, the success of biosurfactant production hinges on the creation of less expensive processes, particularly in the aspect of substrates, which account for $10-30 \%$ of total production costs $[35,36]$. To address this problem, processes 


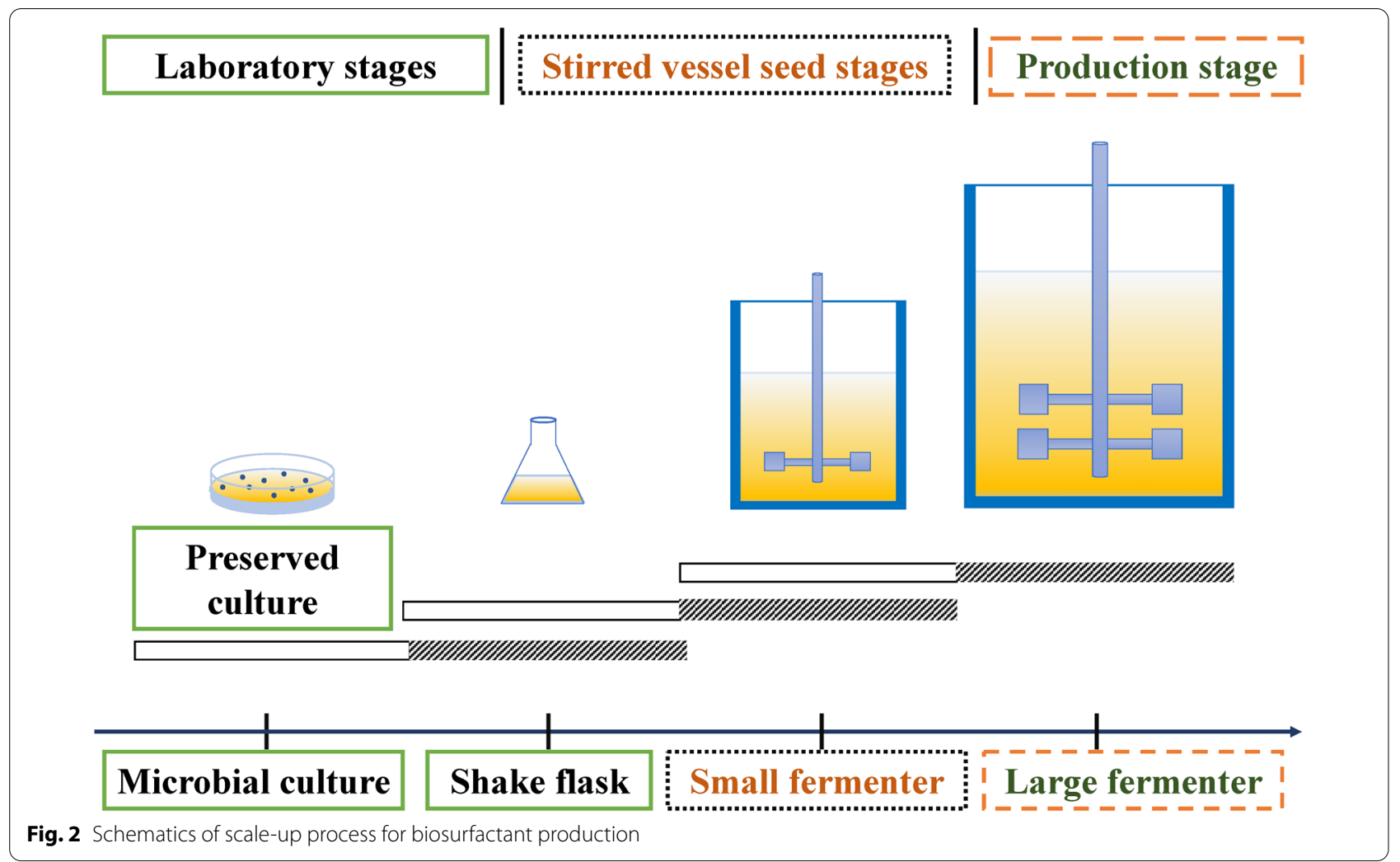

could be linked with the use of waste as substrates which would minimize pollution while balancing overall costs $[37,38]$. This method lowers the cost of waste treatment while also providing the opportunity to benefit from the selling of the biosurfactant. Industrial, agricultural, food waste, and other low-cost substrates may be used to improve this situation [39-43]. Furthermore, techniques such as Response Surface Methodology (RSM) and various statistical approaches have been successfully used in several studies to reduce the cost and time consumed for media optimization in order to optimise biosurfactant manufacturing operations [31]. Many studies have also used engineering techniques to increase output and reduce the downstream production costs.

The current review provides an up-to-date study on techniques available for biotransformation of sustainable substrates into value-added products such as biosurfactant, as well as its significant contribution to the generation of a circular bioeconomy. Furthermore, the paper addresses the use of municipal solid waste as a substrate for biosurfactant production, which has yet to be addressed in most studies. It also addresses the myriad of other issues associated with the processing of biosurfactants, as well as the methods used to address these issues. The review also discusses the pretreatment techniques used, as well as the research needs and prospects for using sustainable substrate for biosurfactant production.

\section{Need for waste stream derived cleaner production}

The concept of using the waste stream for the production of useful material is based on the pursuit of a viable and sustainable method for transforming waste into a jewel [44]. It closes the open loop leaving less waste unutilized thereby, causing less harm to the environment and health [45-47]. This circular loop of waste utilization is the best waste reduction and resource recovery option [48-52]. Because, the use of the waste stream for biosurfactant production has many benefits, including lower processing costs, widespread availability of many less expensive/ renewable substrates, and most importantly, the product becomes more environmentally friendly while maintaining its basic functional properties $[53,54]$. Figure 3 depicts the biosurfactant production schematics.

According to the United Nations Environment Programme [55], approximately 93.1 crore tonnes of food waste were produced in 2019, with $61 \%$ coming from residences, $26 \%$ from food service, and $13 \%$ from retail; implying that $17 \%$ of total global food production could be squandered. Similarly, in India, the annual wastage of food is projected to be $68,760,163$ tonnes. Such wastage of food has social and economic consequences along with 


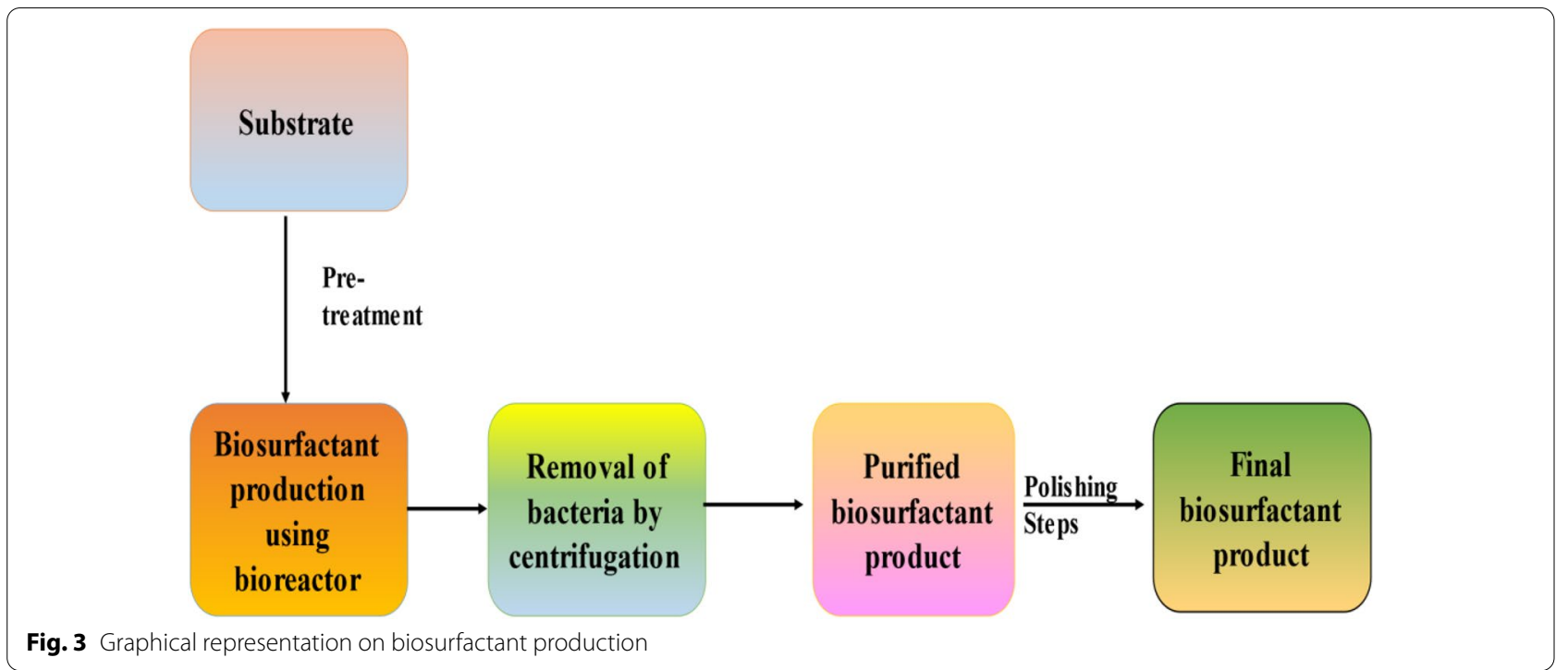

significant environmental consequences such as contributing to greenhouse gas emissions and ecosystem degradation through land conversion and pollution etc. [56, 57]. Hence, utilizing these wastes for the production of bioresource will not solve the existing problem like wastage and pollution but will also lead to the production of more useful resources [58-60].

\section{Suitable substrates for the production of biosurfactant}

Biosurfactant production employing agro-industrial waste and its by-products

Over the last 10 years, there has been a surge in the need for cost-cutting materials which could act as the substrates for biosurfactant production. A variety of renewable and cheap industry-based wastes are being studied and examined for their potential as substrates for biosurfactant production. Among these are the agro-industrial wastes and food residues [61, 62]. This approach of using waste as the substrate is not only helpful in increasing the profitability of the process but also aids in the effective management of the waste that is being generated at an unprecedented pace [63, 64]. However, along with the cost efficiency, factors like the stability, form, and amount to be used, etc., are also taken into consideration while choosing a substrate for biosurfactant production [65, 66].

Microbial species like Halobacteriaceae archaeon, Pseudomonas aeruginosa, Bacillus pumilis, Bacillus licheniformis, Candida tropicalis, etc. are used for the biosurfactant production from agro-industrial waste like date molasses, cassava waste, orange peel, corn steep liquor, sugarcane bagasse, etc. [67, 68]. The production of biosurfactants from agro-industrial waste has several advantages, including increased cost efficiency, large-scale substrate production, increased availability of a broader spectrum of substrates, intact functional properties, environmentally friendly products, and non-toxic to associated microorganisms $[1,3$, 69].

\section{Production of biosurfactants using fruit and vegetable waste} Fruits and vegetables processed for their juices and other products produce a lot of waste like peels of apples, banana, orange, carrots, etc. which have the potential to be used as the substrates for biosurfactant production $[23,70]$. Studies have been done to evaluate the production of biosurfactants using cashew apple juice using Acinetobacter calcocetius [61, 71]. The evaluation showed a reduction in the surface tension up to $17 \%$. Similar studies done on Pseudomonas aeruginosa showed that the highest reduction was about $29.5 \mathrm{mN} / \mathrm{m}$ when Pseudomonas aeruginosa produces rhamnolipids in a mineral medium nourished with cashew apple juice [72].

Another potent waste product that has been taken into consideration for use as a substrate is banana peel, which is the primary by-product of the production and processing of bananas. Banana peel has been used as the only carbon source used in the synthesis of lipopeptides using Halobacteriaceae archaeon [73]. Along with banana peels, carrot peel waste, lime peelings and orange peels have been used to produce rhamnolipids using Pseudomonas aeruginosa $[74,75]$. 


\section{Production of biosurfactants using starch-rich waste}

Extraction of starch from rice, wheat, cassava, potato, and other crops generates a vast amount of wastewater that is high in starch and husks and thus can be used as a feedstock to produce various products including biosurfactants [76, 77]. Bacillus subtilis was used to evaluate potato substrate as an unconventional carbon source for surfactant production. It was also used to produce biosurfactants using cassava wastewater. Furthermore, utilising soybean flour and rice straw as substrate, Bacillus amyloliquefaciens was used to produce lipopeptides [78].

\section{Biosurfactant production employing industrial waste}

The industry-based need for surfactants is on a constant rise. Biosurfactants are used in the bioremediation of hydrocarbon and petroleum polluted soil and groundwater, as well as to degrade other persistent harmful compounds. Biosurfactants are gaining lots of interest in recent times because of their natural origin, low toxicity, and environment-friendly properties. A wide variety of substrates can be used for the production of biosurfactants like dairy-production waste, waste from fruit juice processing industries, oil processing industryderived waste, etc. [39].

Oil processing and production at large scale generates a great amount of waste which are of varied types like soap stock, marine oils, lard, tallow, and/or free fatty acids from the extraction of oil from seeds. The disposal of such huge quantity of waste is an ongoing concern and therefore their use as a substrate for the biosurfactant is garnering a lot of attention from researchers around the globe $[79,80]$. Yeasts have been employed to produce biosurfactants using industrial wastes like oils and free fatty acids due to their ability to produce emulsifiers. Among the yeast species, the species Candida has been most widely employed to produce biosurfactants using oil residues generated from oil processing industries. Other microbes employed to produce biosurfactants using industrial wastes are Corynebacterium aquaticum, Candida bombicola, Candida utilise etc. [81, 82].

\section{Biosurfactant production employing lignocellulosic waste} Lignocellulose is an abundant organic carbon source that is widely available. The cellulose is primarily derived from the plants that are potentially grown for their cellulosic content. The tendency of a microorganism to produce biosurfactant using lignocellulosic media as a substrate was studied on Lactobacillus pentosus, using hydrolysed distilled grape marc which consists of $10.8 \%$ cellulose, $11.2 \%$ hemicellulose, and about 51\% lignin. The growth media was supplemented by yeast extract and corn steep liquor. An intercellular biosurfactant production of about $4.8 \mathrm{mg} / \mathrm{L}$ was reported for this experimental setup. Similarly, the bacterial strain of Bacillus tequilensis, which was isolated from Mexican brines were used to produce both intracellular and extracellular biosurfactant [83-85].

The wide array of studies in context to biosurfactant production using lignocellulosic substrate has highlighted that the possibility of producing a variety of biosurfactants using different carbon sources, but some strains can increase the industrial application potential of the microbial strains and biosurfactants. The lignocellulosic substrates are therefore an excellent cost-efficient carbon source for biosurfactant production. However, the cost of producing biosurfactants rises due to the pre-treatment processes required to ensure that the lignocellulosic residues are available for the microbes to act on. Pre-treatment of lignocellulosic residue includes particle size reduction, pre-hydrolysis, chemical/enzymatic hydrolysis, and drying. The microbe strains that use lignocellulosic residues are Lactobacillus paracasei, Starmerella bombicola, C. bombicola, Cutaneotrichosporon mucoides [86, 87].

\section{Biosurfactant production employing oily and glycerol-based waste and other substrates}

Surfactants are a critical class of chemicals with numerous industrial applications. Thus, the production of biosurfactants from natural substrates not only aids in the management of industry-derived waste, but also in the production of surfactants that are more environmentally friendly and less toxic [88]. Aside from the substrates mentioned above for the production of biosurfactants, some other substrates that can be used for the production of biosurfactants are as follows:

\section{Production of biosurfactants using frying oil wastes}

Many of the agricultural products are processed to produce different food commodities. The residues of this food processing in industries are frequently used frying oils, the nutritional values of which vary depending on the products fried in the oils and the number of times they were reused for frying. The used frying oil has a higher concentration of polar hydrocarbons than the fresh oil and its major constituents are primarily monoglycerides, diglycerides, and triglycerides along with some proportion of free fatty acids $[89,90]$.

Studies have been conducted to investigate the use of waste olive oil and sunflower oil to produce rhamnolipids using Pseudomonas aeruginosa [64]. Similar studies revealed that the Candida bombicola strain was capable of producing sophorolipids from oil waste. Other microbial species that have successfully demonstrated the production of biosurfactants using used frying oil as the substrate medium are Bacillus subtilis, Bacillus 
stratosphericus, Streptomyces, Pseudomonas cepacia, and Mucor circinelloides [91, 92].

\section{Production of biosurfactants using wastes from vegetable oil processing and its by-products}

The processing of vegetable oils generates a large amount of waste which consists of a high concentration of fats, oils, and other associated compounds. These residues are potent contaminants that can lead to both soil and water pollution. Their potency to act as pollutants can be attributed to the low degradability of the lipids compounds that they contain [93]. However, investigative studies have shown that microbial species like Pseudomonas can produce rhamnolipids by using olive oil mill effluents and soybean oil refinery waste as a substrate. In similar studies, Candida sphaerica successfully produced biosurfactants using groundnut oil refinery waste. Other microbial strains that have been successfully employed for the production of biosurfactants using oil processing wastes are Bacillus subtilis, Starmerella bombicola, Trametes versicolor, etc. [94, 95].

\section{Production of biosurfactants using dairy industrial wastes}

Dairy industry produces a significant amount of waste in the form of by-products such as whey, buttermilk, and other derivatives [96]. The Biochemical Oxygen Demand (BOD) of the wastes generated by the dairy industry particularly that of whey is significantly high. The disposal of waste is a problem particularly for those countries that predominantly rely upon the dairy economy. Reportedly, only up to $50 \%$ of the total waste generated from the dairy industry is recycled into other useful products like animal feed, while the remaining portion is considered waste [97].

Using a two-stage cultivation process, [98] successfully demonstrated the production of increased concentrations of sophorolipids of about $422 \mathrm{~g} / \mathrm{L}$. During the first step, Cryptococcus curvatus was cultivated in the deproteinized lactose-rich whey concentrate. This was followed by high-pressure homogenization of the biomass generated in the first step to produce a crude cell extract containing a single cell oil. This oil is then utilized by Candida bombicola for producing sophorolipids [99].

\section{Production of biosurfactants using sugar industrial waste}

Molasses is the main by-product of sugar industries involved in both sugar beet and sugar cane industries. Molasses has garnered a lot of popularity as the substrate used for biosurfactant production. The popularity owes to the fact that molasses is a much low-priced source of sugar than other sources and has an adequate number of other compounds and vitamins [100]. Bacillus subtilis and Pseudomonas aeruginosa bacterial strains have been successfully used in over two decades of research to produce biosurfactants using molasses as a substrate. The molasses-derived biosurfactant exhibited good surface activity and a high emulsification index, indicating its possible application in microbial enhanced oil recovery $[38,61]$.

\section{Pre-treatment of substrates for the production of biosurfactants}

The use of biologically derived substrates to produce more environment-friendly biosurfactants has been a widely researched area around the globe in recent the past. However, a series of pre-treatment is recommended for a wide variety of substrates varying from oil-based substrates, starch substrates, lignocellulosic substrates etc. Pre-treatment of the substrates such as lignin aids in the production of biosurfactants by de-crystallizing the cellulosic structure, decreasing the content in the substrate, and increasing the surface area to enhance the enzymatic activity of the enzymes produced by the microbes using the substrate. The pre-treatment of this substrate biomass makes more sugar available for the microorganism to act upon $[101,102]$.

The primary step of pre-treatment is the size reduction of the substrate feedstock to ensure better utilization of the feedstock by the microorganisms. The substrate is reduced in size using equipment like hammer mill, tub grinder, etc. The particle size reduction helps to increase total surface area, pore size, and contact points for an enzyme to act upon the substrate. The particle size reduction is followed by the pre-hydrolysis treatment which is either done by using liquid ammonia or by using ultrasonication. The use of liquid ammonia has proved to be one of the most efficient delignification techniques and has been popularly been employed in the pre-treatment of lignocellulosic substrates like corn stover. The technique of ultrasonication is a relatively less explored technique for pre-treatment. It is a physical pre-treatment method. It is believed to have the potential to change the substrate structure by de-crystallizing the cellulosic part while retaining a significant amount of substrate and polysaccharide [86, 103].

The substrate is then chemically/enzymatically hydrolyzed. The chemical hydrolysis of substrates can be classified into two types-acid hydrolysis and alkaline hydrolysis. The acid hydrolysis employs inorganic acids like $\mathrm{HCl}$ and $\mathrm{H}_{2} \mathrm{SO}_{4}$ in either concentrated or diluted forms to treat the substrates for biosurfactant production. Although the concentrated form of acid yields better results, it makes the process more expensive. Therefore, dilute-acid hydrolysis has been successfully employed for the pre-treatment of substrates. Similarly, alkalis like potassium, calcium, sodium, and ammonium hydroxides 
have been used for pre-treatment and unlike acid hydrolysis, they cause less sugar degradation. Apart from the chemical alternatives, enzymes derived biologically can also be employed for hydrolysis treatment. Enzymes like $\beta$-glucosidase have been successfully employed in the hydrolysis treatment of bagasse and other substrates [36, 104].

The final step of the pre-treatment process is drying of the substrates (hydrolysates). The substrate is then incorporated into the microbial growth media wherein the substrates are used by the microbes as the primary source of sugar for growth followed by the production of biosurfactant in the form of metabolites [105-107]. Depending on the substrate to be treated, the pre-treatment steps can be used individually or in the sequence outlined above. The pre-treatment process is pivotal for obtaining a high monosaccharide content and limiting the amount of inhibitory compounds in the hydrolysates, which affects the yield, efficiency, and cost of the biosurfactant production process [108]. Figure 4 depicts a schematic image for pre-treatment technology used for biosurfactant production.

\section{Strategies for biosurfactant production using municipal solid waste}

Biosurfactants can be made from a variety of low-cost raw materials that are readily available. The carbon source could be hydrocarbons, carbohydrates or lipids, which could be used individually or in combination. Several low-cost waste materials have been investigated as biosurfactant substrates over the last decade, resulting in a cost-effective strategy [109-112]. Because of the high
$\mathrm{C} / \mathrm{N}$ concentration in MSW, producing biosurfactants from it is a viable and advantageous option [109, 113].

The generation of municipal solid waste has also accelerated as a result of urbanization, a growing population, a thriving economy, and a rapid increase in the living standards of people [114-116]. This poses a significant obstacle to the environment and long-term development $[117,118]$. Thus, adopting an effective Municipal Solid Waste Management (MSWM) plan such as bioconversion of waste materials is regarded as critical for the coming years because it solves the problem of environmental pollution while also providing an option for resource recovery [48, 119-122].

According to the United Nations Environment Programme [55], approximately 93.1 crore tonnes of food waste were produced in 2019, with $61 \%$ coming from residences, $26 \%$ from food service, and 13\% from retail; implying that $17 \%$ of total global food production could be squandered. Avoiding food waste is therefore critical for all those involved in food processing, distribution, and marketing [123]. The proper management of these products at the end of their lifecycle is important in effort to prevent the environmental and social impacts caused by untreated, decomposing food. In addition to wasting energy used to produce food that is not eaten, poorly managed food waste impacts our atmosphere by releasing greenhouse gases during decomposition, pollutes waterways by nutrient and leachate runoff, and can be a disease vector [49].

Food waste is a plentiful and potentially useful source of feedstock. Many studies have shown that the MSW stream in India, contains the highest proportion of

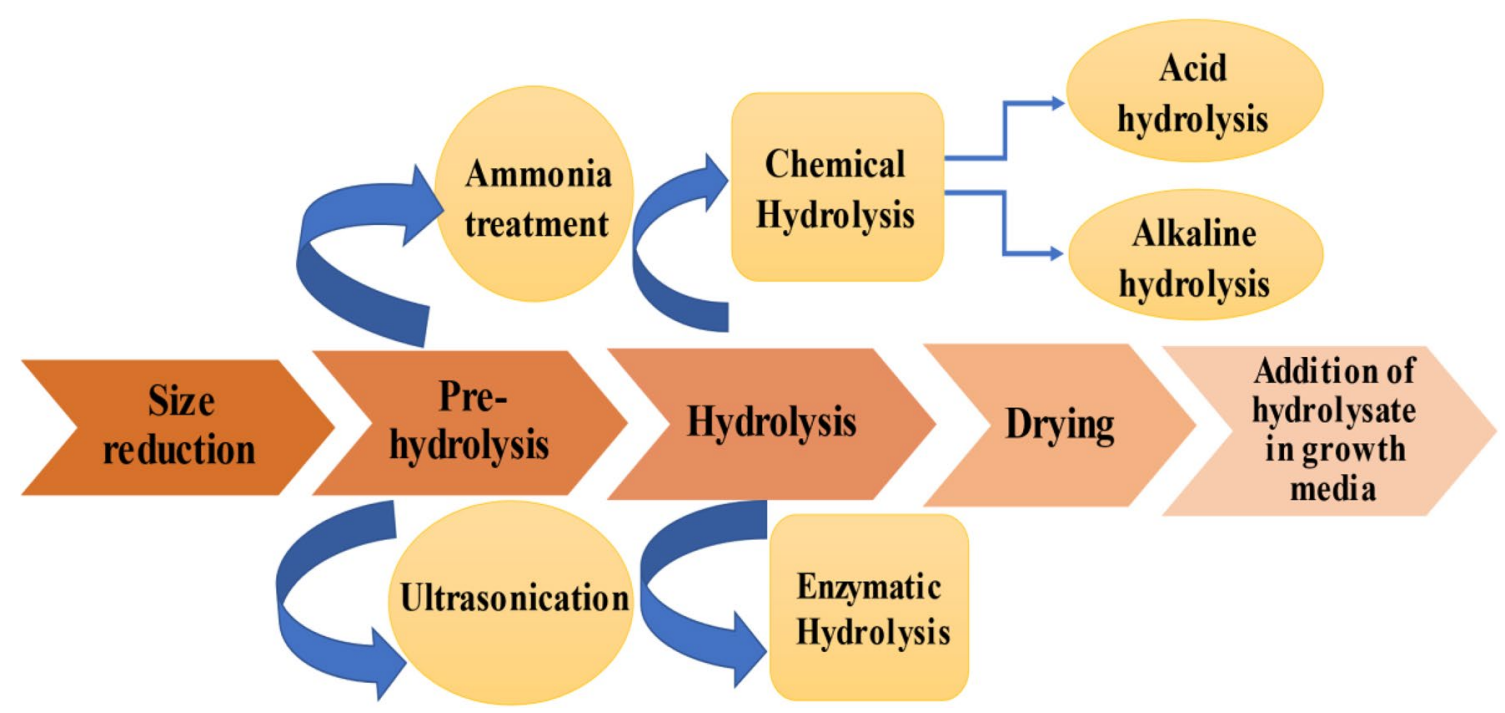

Fig. 4 A schematic image for pre-treatment technology used for biosurfactant production 
biodegradable and recyclable waste, with food waste dominating the organic waste composition [27, 28]. It primarily consists of residual food debris, vegetable waste, leaves, and decaying vegetables. Even so, internationally, poor and middle-income countries produce the majority of MSW with a higher organic/biodegradable content [124]. Valorization of food waste is becoming increasingly critical for achieving Sustainable development goals (SDG's) like food security, environmental protection, etc. [113, 125]. Since food waste contains a high concentration of organic content, traditional disposal and incineration methods can endanger the environment and human health by releasing toxic gases [126, 127]. As a result, using these wastes as a substrate for biosurfactant production offers a renewable method of valuing. Food waste in MSW can be manually separated and used as a substrate for biosurfactant production, lowering production costs and emissions.

Once segregated the food waste can be utilized for biosurfactant production. Many pieces of research have previously been done where food waste has been used as a low-cost substrate for Biosurfactant production. For example, Kitchen waste oil is high in protein and moisture which promotes microbial development. In an experiment [91] successfully used Pseudomonas aeruginosa, isolated from kitchen waste oil, and used it as a fermentation substrate over glucose, glycerol, molasses, and rapeseed oil for the production of biosurfactants. They discovered that the process was optimized at a $\mathrm{pH}$ of 8.0 and a nitrogen source concentration of $2.0 \mathrm{~g} / \mathrm{L}$, and they received a biosurfactant made from a mixture of six rhamnolipid. Table 1 shows the production of different types of biosurfactant using various substrates.

Similarly in another experiment, Starmerella bombicola ATCC 22214 was used by [132] for enzymatic hydrolysis of mixed food waste. They obtained a hydrolysate containing $99.1 \mathrm{~g} / \mathrm{L}$ glucose and $2.4 \mathrm{~g} / \mathrm{L}$ FAN after completing the food waste hydrolysis. Besides, the $\mathrm{C} / \mathrm{N}$ ratio of the mixed food waste hydrolysate used in the study was discovered to be 41 . As a result of the presence of a suitable nutrient balance in food waste hydrolysate, they concluded that it was the best waste feedstock for sophorolipids production. This suggests that food waste could be useful in the development of waste-based bioprocesses for the production of biosurfactants.

Furthermore, fruit and vegetable peelings, which are also a component of the biodegradable fraction of MSW, can be used to create biosurfactant [135] used submerged fermentation to generate rhamnolipid biosurfactant from Pseudomonas aeruginosa MTCC 2297 using a variety of low-cost waste materials like orange peelings, coconut oil cake, lime peelings, carrot peel waste, and banana waste, among others. Orange peel was discovered to be the best substrate, producing $9.18 \mathrm{~g} / \mathrm{L}$ rhamnolipid biosurfactant with a surface tension reduction of up to $31.3 \mathrm{mN} / \mathrm{m}$.

\section{Road blocks and future perspectives}

The concept of using MSW as a substrate for biosurfactant production is exciting, but there are still many obstacles to address before it can be scaled up. There is

Table 1 Biosurfactant production from various feedstocks and microorganism used

\begin{tabular}{|c|c|c|c|c|}
\hline Feedstock & Microorganism used & Type of biosurfactant & Applications & References \\
\hline Fruit and vegetable waste & $\begin{array}{l}\text { Halobacteriaceae archaeon } \\
\text { Pseudomonas aeruginosa } \\
\text { Bacillus subtilis }\end{array}$ & $\begin{array}{l}\text { Lipopeptides } \\
\text { Rhamnolipids } \\
\text { Surfactin }\end{array}$ & $\begin{array}{l}\text { Can be used in bioreme- } \\
\text { diation of oil contaminated } \\
\text { sites, cosmetic industry, and } \\
\text { pharmaceutical industries }\end{array}$ & $\begin{array}{l}\text { Kumar et al. [75]; Paraszkiewicz } \\
\text { et al. [128] } \\
\text { Varjani and Upasani [10] }\end{array}$ \\
\hline Starch rich waste & $\begin{array}{l}\text { Bacillus subtilis } \\
\text { Pseudomonas aeruginosa }\end{array}$ & $\begin{array}{l}\text { Surfactin } \\
\text { Rhamnolipids }\end{array}$ & $\begin{array}{l}\text { Reported use in oil recovery, } \\
\text { environmental protec- } \\
\text { tion, and pharmaceutical } \\
\text { industries }\end{array}$ & $\begin{array}{l}\text { de Andrade et al. [78] } \\
\text { Sharma et al. [9] }\end{array}$ \\
\hline Frying oil waste & $\begin{array}{l}\text { Candida bombicola } \\
\text { Pseudomonas aeruginosa }\end{array}$ & $\begin{array}{l}\text { Sophorolipids } \\
\text { Rhamnolipids }\end{array}$ & $\begin{array}{l}\text { Potential in environmental } \\
\text { applications, bioremedia- } \\
\text { tion of oil and hydrocarbon } \\
\text { contaminated sites }\end{array}$ & $\begin{array}{l}\text { Hasanizadeh et al. [129]; Ozdal } \\
\text { et al. [92] } \\
\text { Santos et al. [130] }\end{array}$ \\
\hline $\begin{array}{l}\text { Oil processing waste and by- } \\
\text { products }\end{array}$ & $\begin{array}{l}\text { Pseudomonas aeruginosa } \\
\text { Bacillus subtilis }\end{array}$ & $\begin{array}{l}\text { Rhamnolipids } \\
\text { Lipopeptides }\end{array}$ & $\begin{array}{l}\text { Remediation of oil and hydro- } \\
\text { carbon contaminated sites }\end{array}$ & $\begin{array}{l}\text { Lourenço et al. [131] } \\
\text { Jadhav et al. [93] } \\
\text { Varjani et al. [64] }\end{array}$ \\
\hline Lignocellulosic wastes & $\begin{array}{l}\text { Candida bombicola } \\
\text { Starmerella bombicola }\end{array}$ & Sophorolipids & $\begin{array}{l}\text { Potential in environmental } \\
\text { applications }\end{array}$ & $\begin{array}{l}\text { Chen et al. [91] } \\
\text { Marcelino et al. [100] } \\
\text { Kaur et al. [132] }\end{array}$ \\
\hline Kitchen organic waste & $\begin{array}{l}\text { Pseudomonas aeruginosa } \\
\text { Starmerella bombicola }\end{array}$ & $\begin{array}{l}\text { Rhamnolipid } \\
\text { Sophorolipid }\end{array}$ & $\begin{array}{l}\text { Reported to be used in devel- } \\
\text { opment of waste-based } \\
\text { bio-processes }\end{array}$ & $\begin{array}{l}\text { Li et al. [133]; Zhao et al. [62] } \\
\text { Liu et al. [134]; Marcelino et al. } \\
\text { [100] }\end{array}$ \\
\hline
\end{tabular}


a scarcity of research to back up the claims that MSW can act as a primary sustainable substrate, thereby reducing biosurfactant production cost and resulting in an increase in business profit. Furthermore, the profitability of these processes is influenced by the composition of waste, which varies from location to location due to the economic class of the people living there, the climate of the place, and so on $[136,137]$. In addition to this the waste segregation techniques followed, transportation costs associated with it, and the energy expenditures that occur during the process; make it more challenging [138].

Similarly, the choice of substrate used is also crucial in determining the yield and efficiency of the end product obtained. Basic considerations particularly concerning substrates like the agro-industrial substrates must consider factors like availability of raw material, the cost of transportation of raw material, and the pre-treatment required before the production process. Efforts should be made to reduce or if possible, eliminate the pre-treatment steps to reduce the cost of production. At the same time, research efforts should be made to find more favourable microbes that can thrive and use the available agroindustrial waste in the less treated form and produce a higher yield of biosurfactants. In this context, recombinant microbes can be employed to treat the available substrate and get the desired surfactant in a higher yield [139].

Downstream processing is plays major role in all the expenses of every biotechnology product [140, 141]. A wide range of analytical techniques has been used to isolate, purify, and classify various biosurfactants. A substantial amount of research has been conducted to increase the productivity and yield of biosurfactants in the upstream production process [142, 143], but a comprehensive study on downstream purification is still lacking. These challenges are opportunities for research groups that should be thoroughly examined and addressed.

\section{Conclusions}

Surfactants produced from renewable raw materials such as waste are increasingly finding their way onto the market chain. The key impediment to biosurfactant commercialization is the high cost of large-scale processing. To address the challenge and compete with synthetic surfactants, low-cost substrate, efficient microorganisms, and appropriate engineering techniques should be used for biosurfactant production. It can be aided by improved production conditions created using less expensive renewable substrates like molasses obtained from the sugar industry, vegetables, and frying oils, dairy waste, agro-industrial wastes, food waste and municipal solid waste, etc. However, the cost of pre-treatment, downstream processing, and, most importantly, largescale production in order to meet market demand remains a barrier in biosurfactant production. As a result, the true value of these processes can only be verified when these studies are successfully applied to a commercially competitive system. The study of these renewable substrates and processes can help researchers and academicians design better experimental setups to refine existing processes and meet the demands of commercial production systems. Waste management is a major challenge in today's world, and using waste materials as substrates can solve both the problem of waste disposal and its long-term adverse environmental impacts.

\section{Acknowledgements \\ The authors would like to thank Gujarat Pollution Control Board for encour- agement and support during manuscript preparation.}

\section{Authors' contributions}

SSM: literature review; writing —original draft; Data curation. YK: literature review; writing —original draft; data curation. SV: conceptualization; supervision; writing - original draft; review and editing; funding acquisition. AP, HHN JSC, JWCW and XTB: review and editing. All authors read and approved the final manuscript.

\section{Availability of data and materials}

All data and material used for preparing the manuscript appear in the submitted article.

\section{Declarations}

\section{Competing interests}

The authors declare that they have no known competing financial interests or personal relationships that could have appeared to influence the work reported in this paper.

\section{Author details}

${ }^{1}$ Gujarat Pollution Control Board, Gandhinagar, Gujarat 382 010, India. ${ }^{2}$ Central University of Gujarat, Gandhinagar, Gujarat 382030, India. ${ }^{3}$ CSIR-Indian Institute of Toxicology Research, Lucknow 226001 , India. ${ }^{4}$ Centre for Technology in Water and Wastewater, School of Civil and Environmental Engineering, University of Technology Sydney, Sydney, NSW 2007, Australia. ${ }^{5}$ Department of Chemical Engineering, National Cheng Kung University, Tainan, Taiwan. ${ }^{6}$ Institute of Bioresource and Agriculture, Hong Kong Baptist University, Kowloon Tong, Hong Kong. ${ }^{7}$ Faculty of Environment and Natural Resources, Ho Chi Minh City University of Technology (HCMUT), Ho Chi Minh City 700000, Vietnam. ${ }^{8}$ Key Laboratory of Advanced Waste Treatment Technology, Vietnam National University Ho Chi Minh (VNU-HCM), Linh Trung Ward, Thu Duc District, Ho Chi Minh City 700000, Vietnam.

Received: 30 April 2021 Accepted: 15 June 2021

Published online: 26 June 2021

\footnotetext{
References

1. Jahan R, Bodratti AM, Tsianou M, Alexandridis P. Biosurfactants, natural alternatives to synthetic surfactants: physicochemical properties and applications. Adv Colloid Interface Sci. 2020;275:102061.

2. Chong H, Li Q. Microbial production of rhamnolipids: opportunities, challenges and strategies. Microb Cell Fact. 2017;16:1-12.

3. Johnson P, Pinfield VJ, Starov V, Trybala A. Effect of synthetic surfactants on the environment and the potential for substitution by biosurfactants. Adv Colloid Interface Sci. 2020;288:102340.

4. Rebello S, Anoopkumar AN, Sindhu R, Binod P, Pandey A, Aneesh EM. Comparative life-cycle analysis of synthetic detergents and
} 
biosurfactants - an overview. Refin Biomass Residues Sustain Energy Bioprod. 2020. https://doi.org/10.1016/B978-0-12-818996-2.00023-5.

5. Akbari S, Abdurahman NH, Yunus RM, Fayaz F, Alara OR. Biosurfactants - a new frontier for social and environmental safety: a mini review. Biotechnol Res Innov. 2018;2:81-90.

6. Drakontis CE, Amin S. Biosurfactants: formulations, properties, and applications. Curr Opin Colloid Interface Sci. 2020. https://doi.org/10. 1016/j.cocis.2020.03.013

7. Liu G, Zhong H, Yang X, Liu Y, Shao B, Liu Z. Advances in applications of rhamnolipids biosurfactant in environmental remediation: a review. Biotechnol Bioeng. 2018;115:796-814.

8. Banat IM, Thavasi R. Microbial biosurfactants and their environmental and industrial applications. CRC Press; 2019.

9. Sharma R, Singh J, Verma N. Production, characterization and environmental applications of biosurfactants from Bacillus amyloliquefaciens and Bacillus subtilis. Biocatal Agric Biotechnol. 2018;16:132-9.

10. Varjani S, Upasani VN. Bioaugmentation of Pseudomonas aeruginosa NCIM 5514-a novel oily waste degrader for treatment of petroleum hydrocarbons. Bioresour Technol. 2021;319:124240.

11. Durval IJB, da Silva IA, Sarubbo LA. Application of microbial biosurfactants in the food industry. In: Microbial biosurfactants. Springer; 2021. p. 1-10

12. Ribeiro BG, Guerra JMC, Sarubbo LA. Biosurfactants: production and application prospects in the food industry. Biotechnol Prog. 2020;36:e3030.

13. Varjani S, Upasani VN, Pandey A. Bioremediation of oily sludge polluted soil employing a novel strain of Pseudomonas aeruginosa and phytotoxicity of petroleum hydrocarbons for seed germination. Sci Total Environ. 2020;737:139766.

14. Markande AR, Patel D, Varjani S. A review on biosurfactants: properties, applications and current developments. Bioresour Technol. 2021;330:124963.

15. Saimmai A, Riansa-Ngawong W, Maneerat S, Dikit P. Application of biosurfactants in the medical field. Walailak J Sci Technol. 2020;17:154-66.

16. Subramaniam MD, Venkatesan D, lyer M, Subbarayan S, Govindasami $V$, Roy A, et al. Biosurfactants and anti-inflammatory activity: a potential new approach towards COVID-19. Curr Opin Environ Sci Health. 2020:17:72-81.

17. Benhur AM, Pingali S, Amin S. Application of biosurfactants and biopolymers in sustainable cosmetic formulation design. J Cosmet Sci. 2020;71:455-80.

18. Kubicki S, Bollinger A, Katzke N, Jaeger K-E, Loeschcke A, Thies S. Marine biosurfactants: biosynthesis, structural diversity and biotechnological applications. Mar Drugs. 2019;17:408.

19. Płaza G, Achal V. Biosurfactants: eco-friendly and innovative biocides against biocorrosion. Int J Mol Sci. 2020;21:2152.

20. Resende AHM, Farias JM, Silva DDB, Rufino RD, Luna JM, Stamford TCM, et al. Application of biosurfactants and chitosan in toothpaste formulation. Colloids Surf B Biointerfaces. 2019;181:77-84.

21. Santos DKF, Rufino RD, Luna JM, Santos VA, Sarubbo LA. Biosurfactants: multifunctional biomolecules of the 21st century. Int J Mol Sci. 2016;17:1-31. https://doi.org/10.3390/ijms17030401.

22. Almeida D, Da Silva RDCS, Brasileiro P, Luna J, Silva MDG, Rufino R, et al. Application of a biosurfactant from Candida tropicalis UCP 0996 produced in low-cost substrates for hydrophobic contaminants removal. Chem Eng Trans. 2018;64:541-6.

23. Chebbi A, Franzetti A, Castro FD, Tovar FHG, Tazzari M, Sbaffoni S, et al. Potentials of winery and olive oil residues for the production of rhamnolipids and other biosurfactants: a step towards achieving a circular economy model. Waste Biomass Valoriz. 2021. https://doi.org/10.1007/ s12649-020-01315-8.

24. Otzen DE. Biosurfactants and surfactants interacting with membranes and proteins: same but different? Biochim Biophys Acta (BBA) Biomembr. 2017;1859:639-49.

25. Jimoh AA, Lin J. Biosurfactant: a new frontier for greener technology and environmental sustainability. Ecotoxicol Environ Saf. 2019;184:109607.

26. Sałek K, Euston SR. Sustainable microbial biosurfactants and bioemulsifiers for commercial exploitation. Process Biochem. 2019;85:143-55.

27. Singh S. Solid waste management in urban india: imperatives for improvement. Observer Research Foundation; 2020.
28. Singh S, Kumar V, Singh S, Dhanjal DS, Datta S, Sharma D, et al. Biosurfactant-based bioremediation. In: Bioremediation of pollutants. Elsevier; 2020. p. 333-58.

29. Varjani S, Rakholiya P, Ng HY, Taherzadeh MJ, Ngo HH, Chang J-S, et al. Bio-based rhamnolipids production and recovery from waste streams: status and perspectives. Bioresour Technol. 2020;319:124213.

30. The 360 research reports. https://www.360researchreports.com/globalbiosurfactants-market-17043331. Accessed 23 Apr 2021.

31. Singh $P$, Patil $Y$, Rale V. Biosurfactant production: emerging trends and promising strategies. J Appl Microbiol. 2019;126:2-13.

32. Bertrand B, Martínez-Morales F, Rosas-Galván NS, Morales-Guzmán D, Trejo-Hernández MR. Statistical design, a powerful tool for optimizing biosurfactant production: a review. Colloids Interfaces. 2018;2:36.

33. Cruz JM, Hughes C, Quilty B, Montagnolli RN, Bidoia ED. Agricultural feedstock supplemented with manganese for biosurfactant production by Bacillus subtilis. Waste Biomass Valoriz. 2018;9:613-8.

34. Schultz J, Rosado AS. Extreme environments: a source of biosurfactants for biotechnological applications. Extremophiles. 2020;24:189-206.

35. Ahmad Z, Crowley D, Marina N, Jha SK. Estimation of biosurfactant yield produced by Klebseilla sp. FKOD36 bacteria using artificial neural network approach. Measurement. 2016;81:163-73.

36. Tan YN, Li Q. Microbial production of rhamnolipids using sugars as carbon sources. Microb Cell Fact. 2018;17:1-13.

37. Ejike Ogbonna K, Victor Agu C, Okonkwo CC, Tochukwu Ughamba K, Akor J, Njoku OU. Use of Spondias Mombin fruit pulp as a substrate for biosurfactant production. Bioengineered. 2021;12:1-12.

38. Martins PC, Martins VG. Biosurfactant production from industrial wastes with potential remove of insoluble paint. Int Biodeterior Biodegrad. 2018;127:10-6.

39. Das AJ, Kumar R. Utilization of agro-industrial waste for biosurfactant production under submerged fermentation and its application in oil recovery from sand matrix. Bioresour Technol. 2018;260:233-40.

40. Fontes GC, Ramos NM, Amaral PFF, Nele M, Coelho MAZ. Renewable resources for biosurfactant production by Yarrowia lipolytica. Braz J Chem Eng. 2012;29:483-94.

41. Marques NSAA, Silva IG, Cavalcanti DL, Maia PCSV, Santos VP, Andrade RFS, et al. Eco-friendly bioemulsifier production by Mucor circinelloides UCP0001 isolated from mangrove sediments using renewable substrates for environmental applications. Biomolecules. 2020;10:365.

42. Pele MA, Ribeaux DR, Vieira ER, Souza AF, Luna MAC, Rodríguez DM, et al. Conversion of renewable substrates for biosurfactant production by Rhizopus arrhizus UCP 1607 and enhancing the removal of diesel oil from marine soil. Electron J Biotechnol. 2019;38:40-8.

43. Thavasi R, Jayalakshmi S, Balasubramanian T, Banat IM. Biosurfactant production by Corynebacterium kutscheri from waste motor lubricant oil and peanut oil cake. Lett Appl Microbiol. 2007;45:686-91.

44. Pandey AK, Gaur VK, Udayan A, Varjani S, Kim S-H, Wong JWC. Biocatalytic remediation of industrial pollutants for environmental sustainability: research needs and opportunities. Chemosphere. 2021;272:129936.

45. Feng S, Ngo HH, Guo W, Chang SW, Nguyen DC, Cheng D, Varjani S, Lei Z, Liu Y. Roles and applications of enzymes for resistant pollutants removal in wastewater treatment. Bioresour Technol. 2021. https://doi. org/10.1016/j.biortech.2021.125278.

46. Jiménez-Peñalver P, Rodríguez A, Daverey A, Font X, Gea T. Use of wastes for sophorolipids production as a transition to circular economy: state of the art and perspectives. Rev Environ Sci Bio/Technol. 2019;18:413-35.

47. Usmani Z, Kumar V, Varjani S, Gupta P, Rani R, Chandra A. Municipal solid waste to clean energy system. Curr Dev Biotechnol Bioeng. 2020. https://doi.org/10.1016/b978-0-444-64321-6.00011-2.

48. Khanal SK, Varjani S, Lin CSK, Awasthi MK. Waste-to-resources: opportunities and challenges. Bioresour Technol. 2020;317:123987.

49. Luo L, Kaur G, Zhao J, Zhou J, Xu S, Varjani S, Wong J. Optimization of water replacement during leachate recirculation for two-phase food waste anaerobic digestion system with off-gas diversion. Bioresour Technol. 2021;335:125234. https://doi.org/10.1016/j.biortech.2021. 125234.

50. Maina S, Kachrimanidou V, Koutinas A. A roadmap towards a circular and sustainable bioeconomy through waste valorization. Curr Opin Green Sustain Chem. 2017:8:18-23. 
51. Mishra B, Varjani S, Agarwal DC, Mandal SK, Ngo HH, Taherzadeh MJ, Chang JS, You S, Guo W. Engineering biocatalytic material for the remediation of pollutants: a comprehensive review. Environ Technol Innov. 2020;20:101063. https://doi.org/10.1016/j.eti.2020.101063.

52. Seroka-Stolka O, Ociepa-Kubicka A. Green logistics and circular economy. Transp Res Procedia. 2019;39:471-9.

53. Mishra B, Varjani S, Iragavarapu GP, Ngo HH, Guo W, Vishal B. Microbial fingerprinting of potential biodegrading organisms. Curr Pollut Rep. 2019. https://doi.org/10.1007/s40726-019-00116-5.

54. Sajna KV, Gottumukkala LD. Biosurfactants in bioremediation and soil health. In: Microbes and enzymes in soil health and bioremediation. Springer; 2019. p. 353-78.

55. United Nations Environment Programme. Food waste index. 2021. https://www.unep.org/resources/report/unep-food-wasteindex-report-2021.

56. Bilska B, Tomaszewska M, Kołożyn-Krajewska D, Szczepański K, Łaba R, Łaba S. Environmental aspects of food wastage in trade — a case study. Environ Prot Nat Resour Srodowiska i Zasobów Nat. 2020;31:24-34.

57. Sun SK, Lu YJ, Gao H, Jiang TT, Du XY, Shen TX, et al. Impacts of food wastage on water resources and environment in China. J Clean Prod. 2018;185:732-9.

58. Moshtagh B, Hawboldt K, Zhang B. Optimization of biosurfactant production by Bacillus subtilis N3-1P using the brewery waste as the carbon source. Environ Technol. 2018;40(25):3371-80. https://doi.org/ 10.1080/09593330.2018.1473502.

59. Sharma M, Usmani Z, Gupta VK, Bhat R. Valorization of fruits and vegetable wastes and by-products to produce natural pigments. Crit Rev Biotechnol. 2021;41:1-42.

60. Varjani S, Rakholiya P, Shindhal T, Shah AV, Ngo HH. Trends in dye industry effluent treatment and recovery of value added products. J Water Process Eng. 2021;39:101734.

61. Rivera ÁD, Urbina MÁM, y López VEL. Advances on research in the use of agro-industrial waste in biosurfactant production. World J Microbiol Biotechnol. 2019;35:1-18.

62. Zhao F, Shi R, Cui Q, Han S, Dong H, Zhang Y. Biosurfactant production under diverse conditions by two kinds of biosurfactantproducing bacteria for microbial enhanced oil recovery. J Pet Sci Eng. 2017:157:124-30.

63. Rene ER, Ge J, Kumar G, Singh RP, Varjani S. Resource recovery from wastewater, solid waste, and waste gas: engineering and management aspects. Environ Sci Pollut Res. 2020;27:17435-7.

64. Varjani S, Lee $D$, Zhang Q. Valorizing agricultural biomass for sustainable development: biological engineering aspects. Bioengineered. 2020. https://doi.org/10.1080/21655979.2020.1759185.

65. Das AJ, Kumar R. Production of biosurfactant from agro-industrial waste by Bacillus safensis J2 and exploring its oil recovery efficiency and role in restoration of diesel contaminated soil. Environ Technol Innov. 2019;16:100450.

66. de Oliveira Schmidt VK, de Souza Carvalho J, de Oliveira D, de Andrade CJ. Biosurfactant inducers for enhanced production of surfactin and rhamnolipids: an overview. World J Microbiol Biotechnol. 2021;37:1-15.

67. Geetha SJ, Banat IM, Joshi SJ. Biosurfactants: production and potential applications in microbial enhanced oil recovery (MEOR). Biocatal Agric Biotechnol. 2018;14:23-32.

68. Hippolyte MT, Augustin M, Hervé TM, Robert N, Devappa S. Application of response surface methodology to improve the production of antimicrobial biosurfactants by Lactobacillus paracasei subsp. tolerans N2 using sugar cane molasses as substrate. Bioresour Bioprocess. 2018:5:1-16.

69. Khan AHA, Tanveer S, Alia S, Anees M, Sultan A, Iqbal M, et al. Role of nutrients in bacterial biosurfactant production and effect of biosurfactant production on petroleum hydrocarbon biodegradation. Ecol Eng. 2017;104:158-64.

70. Sharma P, Gaur VK, Kim S-H, Pandey A. Microbial strategies for bio-transforming food waste into resources. Bioresour Technol. 2020;299:122580.

71. Rocha MVP, Oliveira AHS, Souza MCM, Gonçalves LRB. Natural cashew apple juice asfermentation medium for biosurfactant production by Acinetobacter calcoaceticus. World J Microbiol Biotechnol. 2006;22(12):1295-9. https://doi.org/10.1007/s11274-006-9175-8.

72. Rocha M, Souza M, Benedicto S, Bezerra M, Macedo G, Saavedra Pinto G, Gonçalves L. Production of Biosurfactant by Pseudomonas aeruginosa
Grown on Cashew Apple Juice. Appl Biochem Biotecnol. 2007. https:// doi.org/10.1007/978-1-60327-181-3_17.

73. Chooklin CS, Maneerat S, Saimmai A. Utilization of banana peel as a novel substrate for biosurfactant production by Halobacteriaceae archaeon AS65. Appl Biochem Biotechnol. 2014;173:624-45.

74. Kourmentza C, Freitas F, Alves V, Reis MAM. Microbial conversion of waste and surplus materials into high-value added products: the case of biosurfactants. In: Microbial applications, vol. 1. Springer; 2017. p. 29-77.

75. Kumar AP, Janardhan A, Viswanath B, Monika K, Jung J-Y, Narasimha G. Evaluation of orange peel for biosurfactant production by Bacillus licheniformis and their ability to degrade naphthalene and crude oil. 3 Biotech. 2016;6:43.

76. Gurjar J, Sengupta B. Production ofsurfactin from rice mill polishing residue by submerged fermentation using Bacillus subtilis MTCC 2423. Bioresour Technol. 2015;189:243-9. https://doi.org/10.1016/j.biortech. 2015.04.013.

77. Bhange K, Chaturvedi V, Bhatt R. Simultaneous production of detergent stable keratinolytic protease, amylase and biosurfactant by Bacillus subtilis PF1 using agro industrial waste. Biotechnol Rep. 2016;10:94-104.

78. De Andrade CJ, De Andrade LM, Rocco SA, Sforça ML, Pastore GM, Jauregi P. A novel approach for the production and purification of mannosylerythritol lipids (MEL) by Pseudozyma tsukubaensis using cassava wastewater as substrate. Sep Purif Technol. 2017;180:157-67.

79. Chebbi A, Hentati D, Zaghden H, Baccar N, Rezgui F, Chalbi M, et al. Polycyclic aromatic hydrocarbon degradation and biosurfactant production by a newly isolated Pseudomonas sp. strain from used motor oil-contaminated soil. Int Biodeterior Biodegrad. 2017;122:128-40.

80. Hentati D, Chebbi A, Hadrich F, Frikha I, Rabanal F, Sayadi S, et al. Production, characterization and biotechnological potential of lipopeptide biosurfactants from a novel marine Bacillus stratosphericus strain FLU5. Ecotoxicol Environ Saf. 2019;167:441-9.

81. Eldin AM, Kamel Z, Hossam N. Isolation and genetic identification of yeast producing biosurfactants, evaluated by different screening methods. Microchem J. 2019;146:309-14.

82. Kaur K, Sangwan S, Kaur H. Biosurfactant production by yeasts isolated from hydrocarbon polluted environments. Environ Monit Assess. 2017:189:1-13.

83. Bezerra KGO, Gomes UVR, Silva RO, Sarubbo LA, Ribeiro E. The potential application of biosurfactant produced by Pseudomonas aeruginosa TGC01 using crude glycerol on the enzymatic hydrolysis of lignocellulosic material. Biodegradation. 2019;30:351-61.

84. Joy S, Rahman PKSM, Khare SK, Soni SR, Sharma S. Statistical and sequential (fill-and-draw) approach to enhance rhamnolipid production using industrial lignocellulosic hydrolysate C6 stream from Achromobacter sp. (PS1). Bioresour Technol. 2019;288:121494.

85. Panjiar N, Mattam AJ, Jose S, Gandham S, Velankar HR. Valorization of xylose-rich hydrolysate from rice straw, an agroresidue, through biosurfactant production by the soil bacterium Serratia nematodiphila. Sci Total Environ. 2020;729:138933.

86. Joy S, Rahman PKSM, Khare SK, Sharma S. Production and characterization of glycolipid biosurfactant from Achromobacter sp. (PS1) isolate using one-factor-at-a-time (OFAT) approach with feasible utilization of ammonia-soaked lignocellulosic pretreated residues. Bioprocess Biosyst Eng. 2019;42:1301-15.

87. Konishi M, Yoshida Y, Horiuchi J. Efficient production of sophorolipids by Starmerella bombicola using a corncob hydrolysate medium. J Biosci Bioeng. 2015;119:317-22.

88. Vecino X, Cruz JM, Moldes AB, Rodrigues LR. Biosurfactants in cosmetic formulations: trends and challenges. Crit Rev Biotechnol. 2017;37:911-23.

89. e Silva NMPR, Rufino RD, Luna JM, Santos VA, Sarubbo LA. Screening of Pseudomonas species for biosurfactant production using low-cost substrates. Biocatal Agric Biotechnol. 2014;3:132-9.

90. Ramírez IM, Tsaousi K, Rudden M, Marchant R, Alameda EJ, Román MG, et al. Rhamnolipid and surfactin production from olive oil mill waste as sole carbon source. Bioresour Technol. 2015;198:231-6.

91. Chen C, Sun N, Li D, Long S, Tang X, Xiao G, et al. Optimization and characterization of biosurfactant production from kitchen waste oil using Pseudomonas aeruginosa. Environ Sci Pollut Res. 2018;25:14934-43. 
92. Ozdal M, Gurkok S, Ozdal OG. Optimization of rhamnolipid production by Pseudomonas aeruginosa OG1 using waste frying oil and chicken feather peptone. 3 Biotech. 2017;7:1-8.

93. Jadhav JV, Pratap AP, Kale SB. Evaluation of sunflower oil refinery waste as feedstock for production of sophorolipid. Process Biochem. 2019;78:15-24.

94. Konkol D, Szmigiel I, Domżał-Kędzia M, Kułażyński M, Krasowska A Opaliński S, et al. Biotransformation of rapeseed meal leading to production of polymers, biosurfactants, and fodder. Bioorg Chem. 2019;93:102865.

95. Luna JM, Rufino RD, Jara AMAT, Brasileiro PPF, Sarubbo LA. Environmental applications of the biosurfactant produced by Candida sphaerica cultivated in low-cost substrates. Colloids Surf A Physicochem Eng Asp. 2015;480:413-8.

96. Adesra A, Srivastava V, Varjani S. Valorization of dairy wastes: integrative approaches for value added products. Indian J Microbiol. 2021. https:// doi.org/10.1007/s12088-021-00943-5.

97. Ahmad T, Aadil RM, Ahmed H, ur Rahman U, Soares BCV, Souza SLQ, et al. Treatment and utilization of dairy industrial waste: a review. Trends Food Sci Technol. 2019:88:361-72.

98. Daniel H-J, Reuss M, Syldatk C. Production of sophorolipids in high concentration from deproteinized whey and rapeseed oil in a two stage fed batch process using Candida bombicola ATCC 22214 and Cryptococcus Curvatus ATCC 20509. Biotechnol Lett. 1998;20:1153-6.

99. Daverey A, Pakshirajan K, Sumalatha S. Sophorolipids production by Candida bombicola using dairy industry wastewater. Clean Technol Environ Policy. 2011:13:481-8.

100. Marcelino PRF, Peres GFD, Terán-Hilares R, Pagnocca FC, Rosa CA, Lacerda TM, et al. Biosurfactants production by yeasts using sugarcane bagasse hemicellulosic hydrolysate as new sustainable alternative for lignocellulosic biorefineries. Ind Crops Prod. 2019;129:212-23.

101. Sharma R, Lamsal BP, Colonna WJ. Pretreatment of fibrous biomass and growth of biosurfactant-producing Bacillus subtilis on biomass-derived fermentable sugars. Bioprocess Biosyst Eng. 2016;39:105-13.

102. Verma R, Sharma S, Kundu LM, Pandey LM. Experimental investigation of molasses as a sole nutrient for the production of an alternative metabolite biosurfactant. J Water Process Eng. 2020;38:101632.

103. Behzadnia A, Moosavi-Nasab M, Tiwari BK, Setoodeh P. Lactobacillus plantarum-derived biosurfactant: ultrasound-induced production and characterization. Ultrason Sonochem. 2020;65:105037.

104. Xu Q, Liu X, Zhao J, Wang D, Wang Q, Li X, et al. Feasibility of enhancing short-chain fatty acids production from sludge anaerobic fermentation at free nitrous acid pretreatment: role and significance of Tea saponin. Bioresour Technol. 2018:254:194-202.

105. Agrawal R, Verma A, Singhania RR, Varjani S, Di Dong C, Patel AK. Current understanding of the inhibition factors and their mechanism of action for the lignocellulosic biomass hydrolysis. Bioresour Technol. 2021;332:125042.

106. Goshadrou A. A novel sequential ultrasound-rhamnolipid assisted [EMIM] OAc pretreatment for enhanced valorization of invasive Cogongrass to bioethanol. Fuel. 2021;290:119997.

107. Kavitha S, Kannah RY, Gunasekaran M, Nguyen DD, Ala'a H, Park J-H, et al. Effect of low intensity sonic mediated fragmentation of anaerobic granules on biosurfactant secreting bacterial pretreatment: energy and mass balance analysis. Bioresour Technol. 2019;279:156-65.

108. Chang K-L, Chen X-M, Wang X-Q, Han Y-J, Potprommanee L, Liu J, et al. Impact of surfactant type for ionic liquid pretreatment on enhancing delignification of rice straw. Bioresour Technol. 2017;227:388-92.

109. Hu J, Luo J, Zhu Z, Chen B, Ye X, Zhu P, et al. Multi-scale biosurfactant production by Bacillus subtilis using tuna fish waste as substrate. Catalysts. 2021;11:456.

110. Magalhães ERB, Silva FL, Sousa MADSB, Dos Santos ES. Use of different agroindustrial waste and produced water for biosurfactant production. Biosci Biotechnol Res Asia. 2018;15:17-26.

111. Ribeiro BG, dos Santosb MM, da Silvac IA, Meirad HM, de Oliveirad AM, Guerrab JMC, et al. Study of the biosurfactant production by Saccharomyces cerevisiae Urm 6670 using agroindustrial waste. Chem Eng. 2020. https://doi.org/10.3303/CET2079011.

112. Sari SK, Trikurniadewi N, Ibrahim SNMM, Khiftiyah AM, Abidin AZ, Nurhariyati T. Bioconversion of agricultural waste hydrolysate from lignocellulolytic mold into biosurfactant by Achromobacter sp. BP (1) 5 . Biocatal Agric Biotechnol. 2020;24:101534.

113. Manu MK, Li D, Liwen L, Jun Z, Varjani S, Wong JWC. A review on nitrogen dynamics and mitigation strategies of food waste digestate composting. Bioresour Technol. 2021;334:125032.

114. Hosseinalizadeh R, Izadbakhsh H, Shakouri H. A planning model for using municipal solid waste management technologies-considering energy, economic, and environmental impacts in Tehran-Iran. Sustain Cities Soc. 2021:65:102566.

115. Koka RK, Pilli K, Das S, Meghana KT. Chapter-2 Municipal solid waste management and MSW compost impact on soil fertility. In: Current research in soil fertility. Delhi: AkiNik Publications; 2020. p. 33.

116. Rajmohan KS, Ramya C, Varjani S. Trends and advances in bioenergy production and sustainable solid waste management. Energy Environ. 2019. https://doi.org/10.1177/0958305×19882415.

117. Ayeleru OO, Okonta FN, Ntuli F. Municipal solid waste generation and characterization in the City of Johannesburg: a pathway for the implementation of zero waste. Waste Manag. 2018;79:87-97.

118. Harris-Lovett S, Lienert J, Sedlak D. A mixed-methods approach to strategic planning for multi-benefit regional water infrastructure. J Environ Manag. 2019;233:218-37.

119. Heidari R, Yazdanparast $R$, Jabbarzadeh A. Sustainable design of a municipal solid waste management system considering waste separators: a real-world application. Sustain Cities Soc. 2019:47:101457.

120. Mohan SV, Varjani S, Pant D, Sauer M, Chang JS. Circular bioeconomy approaches for sustainability. Bioresour Technol. 2020;318:124084.

121. Sadeghi Ahangar S, Sadati A, Rabbani M. Sustainable design of a municipal solid waste management system in an integrated closed-loop supply chain network using a fuzzy approach: a case study. J Ind Prod Eng. 2021. https://doi.org/10.1080/21681015.2021.1891146.

122. Shah A, Srivastava V, Mohanty S, Varjani S. Municipal solid waste as a sustainable resource for energy production: state-of-the-art review. J Environ Chem Eng. 2021. https://doi.org/10.1016/j.jece.2021.105717.

123. Varjani S, Shah A, Vyas S, Srivastava V. Processes and prospects on valorizing solid waste for the production of valuable products employing bio-routes: a systematic review. Chemosphere. 2021. https://doi.org/10. 1016/j.chemosphere.2021.130954.

124. Beyene HD, Werkneh AA, Ambaye TG. Current updates on waste to energy (WtE) technologies: a review. Renew Energy Focus. 2018;24:1-11.

125. Sindhu R, Binod P, Nair RB, Varjani S, Pandey A, Gnansounou E. Waste to wealth: valorization of food waste for the production of fuels and chemicals. In: Current developments in biotechnology and bioengineering. Elsevier; 2020. p. 181-97.

126. Dou Z, Toth JD, Westendorf ML. Food waste for livestock feeding: feasibility, safety, and sustainability implications. Glob Food Sec. 2018;17:154-61.

127. Ites S, Smetana S, Toepfl S, Heinz V. Modularity of insect production and processing as a path to efficient and sustainable food waste treatment. J Clean Prod. 2020;248:119248.

128. Paraszkiewicz K, Bernat P, Kuśmierska A, Chojniak J, Płaza G. Structural identification of lipopeptide biosurfactants produced by Bacillus subtilis strains grown on the media obtained from renewable natural resources. J Environ Manag. 2018;209:65-70. https://doi.org/10.1016/j. jenvman.2017.12.033.

129. Hasanizadeh P, Moghimi H, Hamedi J. Biosurfactant production by Mucor circinelloides on waste frying oil and possible uses in crude oil remediation. Water Sci Technol. 2017;76:1706-14. https://doi.org/10. 2166/wst.2017.338.

130. Santos E, Teixeira M, Converti A, Porto A, Sarubbo L. Production of a new lipoprotein biosurfactant by Streptomyces sp. DPUA1566 isolated from lichens collected in the Brazilian Amazon using agroindustry wastes. Biocatal Agric Biotechnol. 2019;17:142-50. https://doi.org/10. 1016/j.bcab.2018.10.014.

131. Lourenço L, Alberton Magina M, Tavares L, Ulson G, de Souza S, García Román M, Altmajer Vaz D. Biosurfactant production by Trametes versicolor grown on two-phase olive mill waste in solid-state fermentation. Environ Technol. 2017;39:3066-76. https://doi.org/10.1080/09593330. 2017.1374471. 
132. Kaur G, Wang H, To MH, Roelants SLKW, Soetaert W, Lin CSK. Efficient sophorolipids production using food waste. J Clean Prod. 2019:232:1-11.

133. Li P, Zeng Y, Xie Y, Li X, Kang Y, Wang Y, Xie T, Zhang Y. Effect of pretreatment on the enzymatichydrolysis of kitchen waste for xanthan production. Bioresour Technol. 2017;2017(223):84-90. https://doi.org/ 10.1016/j.biortech.2016.10.035.

134. Liu W, Dong Z, Sun D, Chen Y, Wang S, Zhu J, Liu C. Bioconversion of kitchen wastes intobioflocculant and its pilot-scale application in treating iron mineral processing wastewater. Bioresour Technol. 2019;288: https://doi.org/10.1016/j.biortech.2019.121505.

135. George S, Jayachandran K. Analysis of rhamnolipid biosurfactants produced through submerged fermentation using orange fruit peelings as sole carbon source. Appl Biochem Biotechnol. 2009;158:694-705.

136. Cheng J, Shi F, Yi J, Fu H. Analysis of the factors that affect the production of municipal solid waste in China. J Clean Prod. 2020;259:120808

137. Fodor Z, Klemeš JJ. Waste as alternative fuel—minimising emissions and effluents by advanced design. Process Saf Environ Prot. 2012;90:263-84

138. Ren X, Liu T, Awasthi M, Varjani S, Pandey A, Zhang Z. Municipal solid waste biorefineries: a case study in China. Waste Biorefinery. 2021. https://doi.org/10.1016/b978-0-12-821879-2.00016-8.
139. Nguyen TT, Thanh $B X, N g o ~ H H$, Nguyen TTD, Nguyen $K Q$, Nguyen HH, Huynh KPH, Némery J, Fujioka T, Duong CH, Dang BT, Varjani S. Nutrient recovery and microalgae biomass production from urine by membrane photobioreactor at low biomass retention times. Sci Total Environ. 2021;785:147423. https://doi.org/10.1016/j.scitotenv.2021.147423.

140. Banat I, Thavasi R. Downstream processing of microbial biosurfactants. In: Microbial biosurfactants and their environmental and industrial applications. CRC Press; 2018. p. 16.

141. Patel S, Homaei A, Patil S, Daverey A. Microbial biosurfactants for oil spill remediation: pitfalls and potentials. Appl Microbiol Biotechnol. 2019;103:27-37.

142. Heryani H, Putra MD. Kinetic study and modeling of biosurfactant production using Bacillus sp. Electron J Biotechnol. 2017:27:49-54.

143. Rahman PKSM, Gakpe E. Production, characterisation and applications of biosurfactants—review. Biotechnology. 2008;7:360-70.

\section{Publisher's Note}

Springer Nature remains neutral with regard to jurisdictional claims in published maps and institutional affiliations.
Ready to submit your research? Choose BMC and benefit from:

- fast, convenient online submission

- thorough peer review by experienced researchers in your field

- rapid publication on acceptance

- support for research data, including large and complex data types

- gold Open Access which fosters wider collaboration and increased citations

- maximum visibility for your research: over 100M website views per year

At BMC, research is always in progress.

Learn more biomedcentral.com/submissions 